\title{
Education on the impact of reverse osmosis (ro) drinking water toward health in village pb Selayang II Medan
}

\author{
Jansen Silalahi ${ }^{*}$, Siti Morin Sinaga ${ }^{1}$, Nahitma Ginting ${ }^{1}$, Fathur Rahman ${ }^{1}$ \\ ${ }^{1}$ Department of Pharmaceutical Chemistry, University of North Sumatra \\ *Email:jansen@usu.ac.id
}

\begin{abstract}
At this time, there is a lot of ready-to-drink drinking water consisting of mineral water and demineralized drinking water such as Reverse Osmosis (RO) both in packets and refills. Drinking water must meet biological, chemical, and physical requirements so that it does not have negative effects on health. One of the chemical requirements is about the main mineral content of calcium and magnesium in drinking water. Based on research results, drinking water with low minerals (usually expressed as low water hardness) if consumed for a long time will cause health problems, for example increasing the risk of several diseases such as cancer, coronary heart disease, and others. Absorption of toxic metals such as $\mathrm{Pb}$ will occur if the minerals calcium and magnesium are very low in drinking water. So, if there is a small amount of $\mathrm{Pb}$ toxic metals in food, it will be easily absorbed by the body when calcium and magnesium levels are low in drinking water. However, if calcium and magnesium are sufficient in drinking water, the absorption of $\mathrm{Pb}$, both in drinking water and other food, will be inhibited or not occur. Means can avoid diseases caused by these toxic metals.

Therefore, the World Health Organization (WHO) determined that the calcium and magnesium content in drinking water each with a minimum requirement is $20 \mathrm{mg}$ of calcium and $10 \mathrm{mg}$ of magnesium in one liter of drinking water. The Indonesian Ministry of Health in 1975 only stated that the maximum calcium content in drinking water was $75 \mathrm{mg} /$ liter of drinking water and there were no minimum requirements. Then the Ministry of Health in 2010 did not include the calcium and magnesium requirements but only the hardness requirements. So low-mineral drinking water will absorb (trap) the minerals present in other foods and dispose of them so that the body lacks minerals in the long run. Water without minerals will also reduce the process of absorption of minerals in digestion, and can even bind minerals from the body if consumed without other food.

Low mineral water is not good as drinking water, especially demineralized drinking water that does not contain minerals can cause health problems especially water without minerals such as RO drinking water. The results showed that the levels of calcium $(\mathrm{Ca})$ and magnesium $(\mathrm{Mg})$ in bottled and refilled drinking water in Medan more did not reach the minimum levels of calcium and magnesium, meaning that drinking water was low in minerals. Even more important is that producers of refilled RO drinking water are in Medan (some claim to get permission from the government) and there is even a bottled RO drinking water product which means getting permission from the Drug and Food Control (POM).
\end{abstract}

Keywords: RO Drinking Water, deminerals, negative impacts

\begin{abstract}
Abstrak
Pada saat ini, sudah banyak air minum siap saji yang terdiri yaitu air mineral dan air minum demineral seperti Reverse Osmosis (RO) baik dalam kemasan ataupun isi ulang. Air minum harus memenuhi syarat biologis, kimia, fisika agar tidak menimgulkan effek negatif terhadap kesehatan. Salah satu syarat kimiawi adalah tentang kandungan mineral utama yakni kalsium dan magnesium dalam air minum. Berdasarkan hasil penelitian, air minum dengan rendah mineral (biasanya dinyatakan sebagai kesadahan air yang rendah) jika dikonsumsi dalam jangka yang lama akan menimbulkan masalah kesehatan, misalnya meningkatkan resiko beberapa penyakit seperti kanker, jantung koroner, dan lain-lain. Penyerapan logam-logam toksis seperti Pb akan terjadi jika mineral kalsium dan magnesium sangat rendah dalam air minum. Maka, jika dalam makanan terdapat logam toksis $\mathrm{Pb}$ dalam jumlah kecilpun, akan gampang diserap oleh tubuh apabila kadar kalsium dan magnesium rendah dalam air minum. Akan tetapi, apabila kalsium dan magnesium cukup dalam air minum maka penyerapan $\mathrm{Pb}$, baik yang terdapat di dalam air minum dan makanan lainnya, akan dihambat atau tidak terjadi. Berarti dapat menghindari penyakit-penyakit yang diakibatkan oleh logam toksis tersebut.

Oleh karena itulah, maka organisasi kesehatan dunia World Health Organization (WHO) menetapkan
\end{abstract}


bahwa kandungan kalsium dan magnesium dalam air minum masing-masing dengan syarat minimalnya adalah kalsium $20 \mathrm{mg}$ dan magnesium $10 \mathrm{mg}$ dalam satu liter air minum. Depkes RI pada tahun 1975 hanya menyatakan kandungan maksimal kalsium dalam air minum adalah $75 \mathrm{mg} /$ liter air minum dan tidak ada syarat minimal. Kemudian Kemenkes pada tahun 2010 tidak mencantumkan persyaratan kalsium dan magnesium tetapi syarat kesadahan saja. Jadi air minum rendah mineral akan menyerap (menjerat) mineral yang ada dalam makanan lain dan membuangnya sehingga tubuh kekurangan mineral dalam jangka yang lama. Air tanpa mineral juga akan mengurangi proses penyerapan mineral pada pencernaan, dan bahkan dapat mengikat mineral dari tubuh jika dikonsumsi tanpa makanan lainnya.

Air minum rendah mineral tidak baik sebagai air minum, apalagi air minum demineral yang sama sekali tidak mengandung mineral dapat menimbulkan masalah kesehatan apalagi air tanpa mineral seperti air minum RO. Hasil penelitian meunjukkan kadar kalsium (Ca) dan magnesium (Mg) di dalam air minum dalam kemasan dan isi ulang di Medan lebih banyak yang tidak memncapai kadar minimal kalsium dan magnesium, berarti air minum rendah mineral. Hal yang lebih penting lagi ialah bahwa produsen air minum RO isi ulang ada di Medan (ada yang mengaku mendapat izin dari pemerintah) dan bahkan ada produk air minum RO di dalam kemasan yang berarti mendapat izin dari Pengawasan Obat dan Makanan (POM).

\section{Kata Kunci: Air Minum RO, demineral, dampak negatif}

\section{PENDAHULUAN}

Masyarakat atau konsumen harus dilindungi dari pengaruh negatif dari makanan dan minuman yang beredar. Pemerintah melalui Badan POM (BPOM) membuat peraturan, melakukan pembinaan produsen dan mengawasi produk makanan dan minuman yang beredar. Produsen harus mematuhi peraturan dan bertanggung jawab akan mutu produk yang dihasilkan, dan masyarakat juga perlu memiliki informasi untuk memilih produk yang akan dikonsumsi.

Pada saat ini air minum dapat dibeli dari unit isi ulang (ada yang mengaku dapat izin dari POM) dan dalam bentuk kemasan yang disebut air minum dalam kemasan (AMDK) dan dapat diperoleh di supermarket. Jenis air minum ini meliputi air mineral (AMDK mineral) dan AMDK demineral atau air minum reverse osmosis (RO). Air minum RO ada dalam bentuk kemasan, yang berarti sudah mendapat izin dari BPOM. Air minum RO adalah air minum yang tidak mengandung mineral, jadi sama seperti air hujan atau air hasil destilasi atau air demineralisata, sangat rendah kandungan mineral. Dari hasil penelitian air RO atau air minum rendah mineral menyebabkan dampak negatif terhadap kesehatan. Masyarakat yang mengonsumsi air rendah mineral apalagi air minum RO dapat meningkatkan resiko penyakit jantung koroner. Berdasarkan fakta ini maka WHO telah memberikan persyaratan air minum harus mengandung kalsium minimal 20 mg/l dan magnesium minimal 10 mg/l air minum (Fox, 1998; Silalahi, 2014).

Berdasarkan kenyataan ini maka perlu dipertimbangkan dan dikaji kembali penertiban peredaran air minum RO baik isi ulang dan air RO dalam kemasan. Hal ini perlu untuk menghindari dampak negatif pada kesehatan masyarakat dalam jangka panjang. Maka perlu dilakukan kajian ilmiah dan diskusi dengan lembaga yang bertanggug jawab pada peredaran air minum. Pada saat ini DinKes telah memberikan izin untuk memproduksi air minum RO di Kota Medan. Sekiranya izin ini dicabut maka akan ada protes karena memang samai saat ini masih diizinkan oleh DepKes tentang peredaran AMDK demineral. Tujuan dari pengabdian ini adalah untuk memberi masukan dan pemahaman melalui suatu diskusi yang intensif secara ilmiah tentang masalah air minum terutama tentang penertiban peredaran air minum RO dengan Dinas Kesehatan adalah lembaga yang berwenag untuk itu, dan juga sangat penting untuk memberikan edukasi kalangan masyarakat tentang dampak negatif dari AMDK demineral (air minum RO) kepada masyarakat.

\section{Permasalahan Mitra}

Pada saat ini, umumnya air minum yang tersedia dalam kemasan terdiri dari dua kelompok, yaitu air mineral dan air minum demineral baik dalam kemasan ataupun isi ulang. Berdasarkan hasil penelitian, air minum dengan rendah mineral (biasanya dinyatakan sebagai kesadahan air yang rendah) jika dikonsumsi dalam jangka yang lama akan menimbulkan masalah kesehatan, misalnya 
meningkatkan resiko beberapa penyakit seperti kanker dan jantung koroner, dan lain-lain. Penyerapan logam-logam toksis seperti $\mathrm{Pb}$ akan terjadi jika mineral kalsium dan magnesium sangat rendah dalam air minum. Maka, jika dalam makanan terdapat logam toksis $\mathrm{Pb}$ dalam jumlah sedikitpun, akan gampang diserap oleh tubuh apabila kadar kalsium dan magnesium rendah dalam air minum. Akan tetapi, apabila kalsium dan magnesium cukup dalam air minum maka penyerapan $\mathrm{Pb}$, baik yang terdapat di dalam air minum dan makanan lainnya, akan dihambat atau tidak terjadi. Berarti dapat menghindari penyakit-penyakit yang diakibatkan oleh logam toksis tersebut (Fox,1998; Kosizek, 2005).

Memang air minum bukanlah semata-mata berperan hanya sebagai sumber mineral kalsium dan magnesium. Akan tetapi jika kandungan kalsium dan magnesium sangat rendah maka akan terjadi gangguan penyerapan kalsium dan magnesium yang terdapat dalam makanan lainnya. Oleh karena itulah, maka organisasi kesehatan dunia World Health Organization (WHO) menetapkan bahwa kandungan kalsium dan magnesium dalam air minum masing-masing dengan syarat minimalnya adalah kalsium $20 \mathrm{mg}$ dan magnesium $10 \mathrm{mg}$ dalam satu liter air minum. Sedangkan menurut Depkes RI hanya menyatakan kandungan maksimal kalsium dalam air minum adalah 75 $\mathrm{mg}$ /liter air minum dan tidak ada syarat minimal. Jadi air minum itu tidak semata-mata sebagai sumber mineral tetapi air dengan kandungan mineral yang rendah akan menyerap (menjerat) mineral yang ada dalam makanan lain dan membuangnya sehingga tubuh kemungkinan kekurangan mineral dalam jangka yang lama (Fox, 1998; Kosizek, 2005).

Air minum demineral seperti air minum Reverse Osmosis (RO) adalah air yang diproses sedemikian rupa dengan alat yang dapat mengolah air minum biasa menjadi air murni. Berarti air minum RO sama sekali tidak mengandung mineral dan juga memang tidak mengandung zat-zat berbahaya baik zat beracun ataupun bakteri. Maka, dengan demikian air minum RO memang menjadi sumber air untuk tubuh. Disamping itu, air RO bebas dari zat beracun dan bakteri. Maka dalam hal ini air minum RO aman dari segi zat beracun atau bakteri patogen. Inilah yang menjadi salah satu manfaat dari air minum RO karena tidak mengandung pencemaran yang berbahaya bagi kesehatan. Akan tetapi, seperti disebutkan di atas tadi bahwa air minum yang rendah mineral dapat menimbulkan masalah kesehatan apalagi air tanpa mineral seperti air minum RO.

Konsumsi air demineral seperti RO dalam jangka yang tidak lama belum menimbulkan gejala-gejala negatif terhadap kesehatan. Tetapi dalam jangka yang lama selama bertahun-tahun konsumsi air RO bisa menyebabkan peningkatan resiko berbagai penyakit seperti jantung koroner dan lain-lain. Ada konsumen yang mengatakan bahwa konsumsi air RO akan terbebas dari resiko penyakit yang diakibatkan oleh zat-zat beracun dan bakteri yang mungkin bisa terdapat pada air minum biasa karena kemungkinan dapat mengandung pencemar yang berdampak negatif. Mereka juga berpendapat bahwa air bukanlah makanan yang berperan sebagai sumber mineral sebab mineral dapat diperoleh dari bahan makanan lain. Disamping itu juga dikatakan bahwa air minum RO lebih efektif untuk proses detoksifikasi. Akan tetapi kenyataannya, dari berbagai hasil penelitian yang lebih akurat bahwa air minum RO akan menyebabkan peningkatan resiko berbagai penyakit jika dikonsumsi dalam jangka waktu yang lama karena air RO bersifat agresif, mengikat mineral-mineral yang dibutuhkan yang terdapat dalam makanan lainnya sehingga penyerapannya akan terganggu.

Maka, dalam jangka yang lama tubuh bisa kekurangan mineral. Apalagi mengkonsumsi air RO tanpa disertai makanan lain yang mungkin terjadi adalah bahwa air RO akan menguras mineral dari cairan tubuh dan berarti hal ini akan berdampak negatif terhadap kesehatan, karena tubuh kekurangan mineral (Fox; 1998; Kozisek, 2005). Maka dapat disimpulkan bahwa mengkonsumsi air minum RO lebih banyak mudaratnya daripada manfaatnya dan sangat diperlukan edukasi tentang pemanfaatan air minum demineral kepada masyarakat. 


\section{METODE PELAKSANAAN}

Pelaksanaan pengabdian kepada masyarakat ini diawali dengan memantau dan pemanfaatan air minum deminral dikalangan masyarakat, kemudian Ketua Lingkungan Gereja Katolik Pasar 6 Padang Bulan Kelurahan PB Selayang II di datangi tentang kesediaan masyarakat sebagai mitra dalam kegiatan ini. Setelah disetujui maka dilakukan edukasi pada pertemuan pertama dan dilakukan edukasi lanjutan untuk mengevaluasi sejauh mana masyarakat telah memahami tentang materi yang diberikan dan penerapannya dalam kehidupan sehari-hari. Beberapa anggota tim pengabdian sudah melakukan pendekatan dan wawancara kepada masyarakat di tempat kegiatan. Ketua Lingkungan dan para warga setempat, sambutannya sangat antusias dan bersedia diberikan penyuluhan, bimbingan dan pelatihan dalam kegiatan edukasi tentang air minum dalam rangka peningkatan kesehatan. Berdasarkan pengamatan dari anggota tim pengabdian yang merupakan salah satu anggota masyarakat di Lingkugan IX Pasar 6 Padang Bulan ternyata keluarga disana sebagain besar mengkonsumsi air demieral seperti air minum RO sebagai air minum sehari-hari.

\section{Solusi Yang Diberikan}

Melihat permasalahan keadaan lingkungan, kesehatan berkaitan dengan air minum RO, maka kami merasa terpanggil untuk member penyuluhan, bimbingan dan pelatihan untuk meningkatkan penggunaan air minum yang sehat untuk kesehatan dan pengetahuan masyarakat setempat sehingga masyarakat setempat nantinya dapat memanfaatkan jenis air minum yang dikonsumsi dalam menunjang kesehatan keluarga, masyarakat dan meningkatkan pengetahuan anggota keluarga masyarakat.

Kegiatan-kegiatan yang diberikan kepada kelompok masyarakat setempat adalah sosialisasi dan edukasi terlebih dahulu berupa ceramah mengenai pengetahuan tentang keluhan yang mungkin sering dialami oleh konsumen air minum RO, selanjutnya diberikan demo dan pelatihan dari pemilihan air minum yang tepat.

\section{Langkah-Langkah yang Dilakukan}

Langkah-langkah kegiatan pelatihan dapat dilakukan oleh tim pengabdian bagi masyarakat dari staf pengajar dan mahasiswa Fakultas Farmasi Universitas Sumatera Utara sebagai berikut.

1. Mendatangi kelompok masyarakat dilingkungan Kelurahan PB Selayang II Pasar 6 Padang Bulan Medan tentang jenis air minum yang aman, bermutu, dan sehat.

2. Memberikan workshop tentang peranan air minum untuk kesehatan.

3. Memberikan edukasi tentang penggunaan air minum yang sehat, serta pola hidup secara umum.

Tim gabungan dari berbagai ilmu Farmasi ini telah berusaha melaksanakan pengabdian kepada masyarakat dengan baik dan dibantu oleh beberapa mahasiswa Fakultas Farmasi USU, dengan inti kegiatan sebagai berikut.

\section{PELAKSANAAN KEGIATAN}

Kegiatan pengabdian kepada masyarakat yang berjudul "Pembelajaran Tentang Dampak Negatif Air Minum Reverse Osmosis (RO) Terhadap Kesehatan" dilakukan dua kali penjejakan yaitu pada pertengahan Juli, awal Agustus 2019. Kegiatan pengabdian kepada masyarakat ini diawali pada pertengahan bulan akhir Agustus 2019 yakni penjejakan ke Ketua Linkungan IX Gerja Katolik Pasar 6 Padang Bulan. Surat persetujuan secara lisan menjadi dasar pertimbangan pengajuan proposal dengan topik (judul) pengabdian "Pembelajaran Tentang Dampak Negatif dari Air Munum Reverse Osmosis (RO) Terhadap Kesehatan". 


\section{Proses Pembelajaran}

Kegiatan pembelajaran disepakati pada hari Minggu 25 Agustus 2019 di Aula Sapadia Swimming Club (Jl.Bunga Raya No.34 A). Kegiatan ini dihadiri oleh peserta dari masyarakat sebanyak sekitar 40 orang. Tim pengabdian ini juga melibatkan para mahasiswa sebanyak 4 orang dan juga hadir pada kegiatan ini. Kedatangan Tim disambut oleh Ketua Lingkungan IX Gereja Katolik Pasar 6 Padang Bulan Medan. Sebelum kegiatan dimulai, terlebih dahulu disediakan bahan berupa fotokopi makalah kepada semua peserta. Makalah yang diberikan adalah artikel yang telah dipublikasikan di Majalah Kedokteran Indonesia dan artikel yang diterbitkan di dalam Buku Pemikiran Guru Besar USU, yang berjudul "Dampak Negatif Air Minum Reverse osmosis (RO) Terhadap Kesehatan.

Setelah persiapan ruangan rampung, kegiatan diawali dengan acara penyampaian kata-kata sambutan baik dari tim dan Ketua Lingkungan. Kegiatan dibuka oleh kepala Ketua Lingkungan sekaligus membuka acara kegiatan. Kegiatan ini dilanjutkan dengan presentasi dari ketua tim. Materi pembelajaran terdiri dari beberapa bagian yaitu (1) fungsi air sebagai zat gizi yang paling penting untuk menopang kehidupan, (2) syarat air minum, (3) peran penting mineral kalsium dan magnesium di dalam air minum, (4) dampak negative dari air minum tanpa mineral. (Lampiran 2). Acara dimulai setelah di buka oleh Ketua Lingkungan IX Gereja Katolik Pasar 6 Padang Bulan Medan. Kegiatan dihadiri oleh sekitar 40 orang (lihat Gambar 1-4).

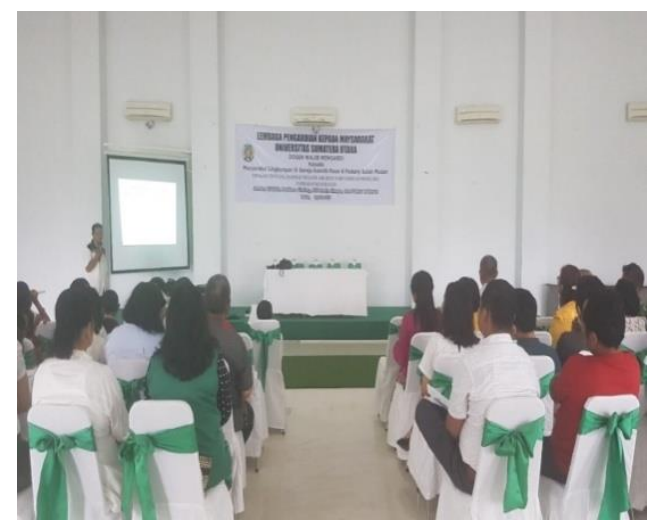

Gambar 3.1 Pembukaan oleh Ketua lingkungan

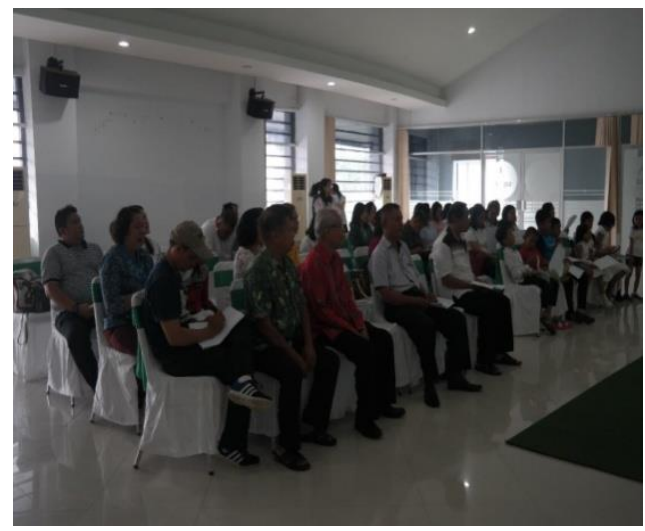

Gambar 2. Peserta Kegiatan Edukasi 


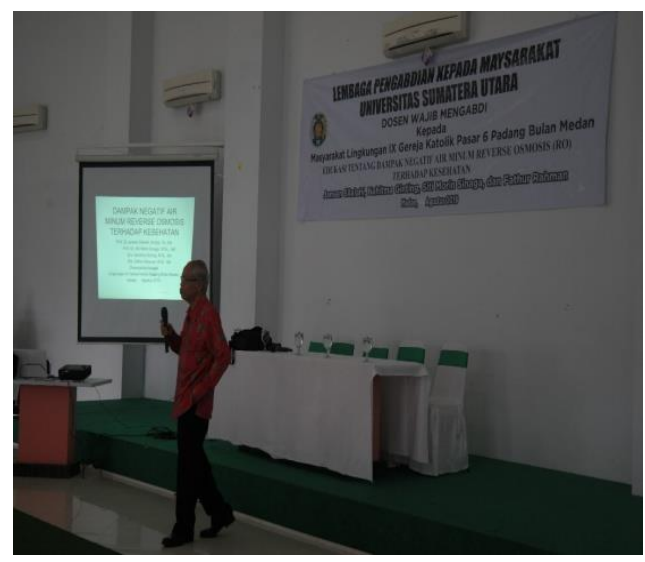

Gambar 3. Presentasi dari Ketua Pengabdian

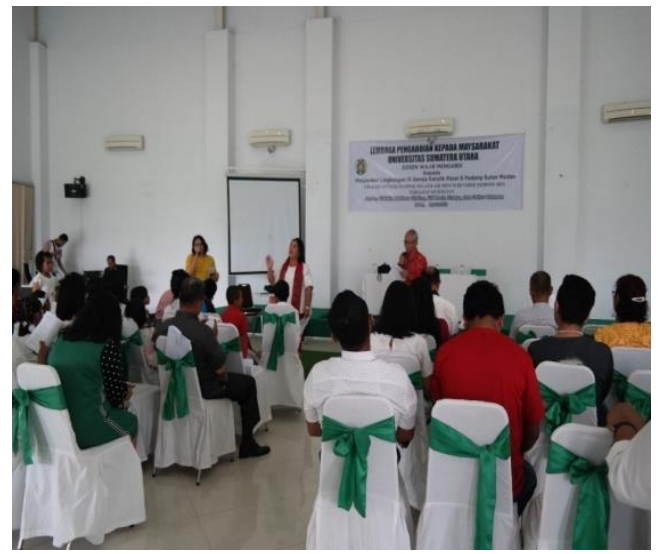

Gambar 4. Diskusi dan Tanya Jawab

\section{HASIL DAN PEMBAHASAN}

Setelah disampaikan materi pengabdian kepada peserta selanjutnya diadakan tanya jawab dengan peserta untuk menanggapi materi pembelajaran. Pada saat diskusi maka muncullah berbagai pertanyaan yang berkaitan dengan topik pengabdian yakni:

1. Apa saja penyakit yang dapat muncul dari konsumsi air minum RO dalam jangka yang lama.

2. Apakah tidak ada manfaat dari air minum RO samasekali.

3. Bagaimana cara untuk mengetahui ciri-ciri /mengidentifikasi air minum RO

4. Kenapa Pemerintah masih memberikan izin peredaran air minum dalam kemasan (AMDK) demineral atau RO.

5. Kenapa DinKes masih memberikan izin untuk memproduksi air minum RO di Kota Medan sampai saat ini.

Maka jawaban dari semua pertanyaan ini sudah dijelaskan sesuai dengan uraian yang telah diutarakan di dalam makalah yang telah dibagikan pada peserta (Daftar pustaka No 3). Mengingat informasi ini bahwa air minum RO berdampak pada kesehatan masyarakat dalam jangka panjang perlu di sosialisasikan kepada masyarakat. Dengan demikian mereka tidak lagi mengonsumsi air minum RO, maka secara perlahan produsen akan mengganti usahanya. Jika ada permohonan baru untuk memperoleh izin untuk memproduksi air minum RO lebih baik ditunda dulu.

1. Jika ada permohonan baru untuk memperoleh izin untuk memproduksi air minum RO lebih baik ditunda dulu.

2. Perlu disampaikan informasi ini/ dilakukan pembelajaran kepada Instansi Pengolah Air bersih untuk air minum seperti PAM Tirtanadi Medan 
3. Dari hasil penelitian yang telah dilakukan ternyata syarat air minum yang baik terkait dengan kandunagan Kalsium dan Magnesium di dalam air minum produksi PAM Tirtanadi Medan masih belum memenuhi syarat WHO.

\section{KESIMPULAN}

Melalui kegiatan ini, masyarakat Lingkungan IX Gereja katolik Pasar 6 Padang Bulan Medan memperoleh pengetahuan yang lebih baik tentang mutu air minum sehat, tentang air minum demineral atau air minum RO dan dampak negatif terhadap kesehatan sehingga meningkatkan kompetensi mereka di dalam melaksanakan tugas untuk mengawasi mutu air minum di dalam kemasan.

\section{SARAN}

Disarankan agar makalah tentang dampak negatif air minum demineral dan RO terhadap kesehatan dapat dipublikasikan secara nasional. Hasil diskusi perlu disampaikan ke Badan Pengawasan Obat dan Makanan Pusat di Jakarta dan Pemerintah Daerah (Propinsi SUMUT) untuk bahan pertimbangan di dalam mengambil kebijakan dan keputusan.

\section{UCAPAN TERIMAKASIH}

Terimakasih kami ucapkan kepada bapak Rektor USU, Wakil Rektor III dan Ketua LPPM USU yang telah mendukung pendanaan pelaksanaan kegiatan Pk Mini dengan dana NON PNPB Universitas Sumatera Utara sesuai dengan Surat Perjanjian Penugasan Pelaksanaan Pengabdian kepada masyarakat program tahun reguler tahun anggaran 2019. Nomor: 327/UN5.2.3.2.1/PPM/2019.

\section{DAFTAR PUSTAKA}

Florencia, M. (2014). Analisis Kalsium, Magnesium dan Timbal Pada Air Mineral dalam Kemasan dan Air Minum Isi Ulang secara Spektrofotometri Serapan Atom. Skripsi. Fakulats Farmasi USU Medan.

Fox, M. (1998). Healthy Water. Portsmouth: Healthy Water Research.

Hutasoit, FTH. (2014). Analisis Mineral Kalsium dan Magnesium Pada Air Minum Tirtanadi di Beberapa Lokasi di Kota Medan. Skripsi. Fakultas Farmasi USU Medan.

Kozisek, F. (2005). Health risk From Drinking Demineralised Water. In: World Health Organization (WHO):Nutriens in Drinking Water. hal. 148-163.

Pasaribu, JH. (2013). Analisis Mineral Kalsium, kalium dan Magnesium pada Beberapa jenis Air Minum Isi Ulang di Kota Medan. Skripsi. Fakultas Farmasi USU.

Silalahi, J. (2014). Dampak Negatif Air Minum Reverse Osmosis (RO) terhadap Kesehatan. $J$ Indon Med Assoc, Vol 64(5), Mei. 2014; 215-217. 